\title{
Subclinical mastitis in pastoralist dairy camel herds in Isiolo, Kenya: Prevalence, risk factors, and antimicrobial susceptibility
}

\author{
D. Seligsohn, ${ }^{1,2 *}$ A-K. Nyman, ${ }^{3}$ M. Younan, ${ }^{4}$ W. Sake, ${ }^{5}$ Y. Persson,,${ }^{1,3}$ S. Bornstein, ${ }^{1}$ M. Maichomo, ${ }^{6}$ \\ K. de Verdier, ${ }^{1}$ J. M. Morrell, ${ }^{2}$ and E. Chenais ${ }^{7}$ \\ ${ }^{1}$ Department of Animal Health and Antimicrobial Strategies, National Veterinary Institute, SE-75189, Uppsala, Sweden \\ ${ }^{2}$ Department of Clinical Sciences, Swedish University of Agricultural Sciences, SE-75007, Uppsala, Sweden \\ ${ }^{3}$ Växa Sverige, SE-10425, Stockholm, Sweden \\ ${ }^{4}$ Food and Agriculture Organization (FAO)-Syria, United Nations Cross-Border Hub, 27010 Sahinbey, Gaziantep, Turkey \\ ${ }^{5}$ Department of Agriculture, Livestock and Fisheries Development, County Government of Marsabit, PO Box 384-60500, Marsabit, Kenya \\ ${ }^{6}$ Kenya Agriculture and Livestock Research Organization, Veterinary Research Institute, 00902, Kikuyu, Nairobi, Kenya \\ ${ }^{7}$ Department of Disease Control and Epidemiology, National Veterinary Institute, SE-75189, Uppsala, Sweden
}

\begin{abstract}
Mastitis is an important constraint to milk production in pastoralist camel (Camelus dromedarius) herds in Kenya. The objective of this study was to investigate the prevalence, risk factors, and bacterial panorama of subclinical mastitis (SCM) in pastoralist camel herds in Isiolo County, Kenya. Furthermore, antimicrobial susceptibility in udder pathogens was studied. A crosssectional sample of 206 camels from 20 milking herds was screened using the California Mastitis Test (CMT), and quarter milk was subjected to bacterial culturing. Isolates were confirmed using MALDI-TOF mass spectrometry analysis, and antimicrobial susceptibility was determined using the broth microdilution method. Interviews focusing on herd management were conducted with camel owners. Subclinical mastitis, defined as a CMT score $\geq 3$ (scale 1 to 5 ) and absence of clinical symptoms in the udder, were present in all visited herds. On the individual level, $46 \%$ of the camels had at least 1 quarter affected with SCM, and on the quarter level the prevalence was $26 \%$. Intramammary infections (IMI) were common; out of 798 quarter milk samples, $33 \%$ yielded conclusive bacterial growth. The sensitivity and specificity of CMT for correctly identifying quarters with IMI were $82 \%$ and $92 \%$, respectively. The most prevalent pathogen was Streptococcus agalactiae (72\% of IMI-positive quarters), followed by non-aureus staphylococci (19\%) and Staphylococcus aureus (13\%). Antimicrobial susceptibility testing revealed that only a low proportion (4.9\%) of Strep. agalactiae isolates was sensitive to tetracycline. For Staph. aureus, $59.1 \%$ of isolates exhibited sensitivity to penicillin. Skin lesions on the teats or udder were a risk factor for SCM. Increased
\end{abstract}

Received October 4, 2019.

Accepted January 10, 2020.

*Corresponding author: dinah.seligsohn@sva.se age, parity, and stage of lactation were associated with increased risk of both SCM and IMI. Older camels with a blind teat or a previous history of mastitis were more likely to be infected with Strep. agalactiae. Hygiene routines for milking were largely absent in the observed herds, and knowledge of adequate milk handling was limited. The poor udder health is likely to depend on multiple factors, most prominently the within-herd maintenance of contagious udder pathogens, in combination with difficult sanitary conditions and lack of awareness among camel keepers. This study showed that in pastoralist camel herds around Isiolo town, SCM and IMI specifically caused by Strep. agalactiae are common udder health problems and are associated with increasing age, parity, and stage of lactation, and skin lesions on the teats and udder. Resistance to tetracycline in Strep. agalactiae was common. Control strategies specifically targeting SCM and adapted to pastorally managed camel herds need to be developed to reduce disease, combat antimicrobial resistance, and improve the livelihoods of pastoralists.

Key words: pastoralist, California Mastitis Test, milking hygiene, udder infection, Camelus dromedarius

\section{INTRODUCTION}

Camels (Camelus dromedarius) are well adapted to harsh environments and can maintain milk production even when feed and water are scarce. They are vital for the subsistence of pastoralists inhabiting arid and semi-arid regions in Africa, the Middle East, and Asia (Köhler-Rollefson et al., 1991; Guliye et al., 2007; Volpato and Howard, 2014). Camel milk provides an important contribution to the livelihoods of the pastoralists, both as a fundamental component of the diet and as an income-generating commodity (Elhadi et al., 2015). One of the most important diseases among dairy animals is mastitis, which reduces milk yield and 
quality (Saleh et al., 2013) and affects animal welfare (Kemp et al., 2008). Economic losses associated with mastitis occur due to rapid milk spoilage and decreased milk yield (Miller et al., 1983; Nielsen et al., 2010), and public health consequences arise from consuming raw milk from affected animals (Matofari et al., 2007; Abdulkadhim, 2012; AlAll et al., 2012).

Clinical mastitis (CM) is easily recognized by camel keepers (Regassa et al., 2013) and is considered a significant constraint to milk production (Farah et al., 2007; Abera et al., 2010). Because subclinical mastitis (SCM) is difficult to assess without diagnostic tests, such as the California Mastitis Test (CMT) or somatic cell counting, camel keepers are less aware of its occurrence and consequences than for CM (Abera et al., 2010; Volpato et al., 2015). Furthermore, SCM is more prevalent than CM in camel dairy herds (Obied et al., 1996; Abera et al., 2010). Intramammary infection in bovines is almost always the cause of SCM (Sandholm, 1995). Other factors, such as age, parity, stage of lactation, season, and use of teat tying to prevent the calf from suckling, have also been shown to be associated with SCM in camels (Abdurahman et al., 1995; Abera et al., 2010; Nagy et al., 2013; Regassa et al., 2013). The CMT has been evaluated for camel milk; however, its sensitivity and specificity for identifying IMI-positive quarters in dromedary camels under pastoralist conditions is little studied (Abdurahman, 1996; Younan et al., 2001). Streptococcus agalactiae, Staphylococcus aureus, and NAS are frequent causes of IMI among camel herds in the Horn of Africa (Abdurahman et al., 1995; Obied et al., 1996; Younan et al., 2001; Regassa et al., 2013). In these studies, microbial identification was restricted to basic culturing, Gram staining, and biochemical tests. More accurate identification methods, such as MALDI-TOF MS analysis or molecular methods, are available and are valuable for a more objective species-specific diagnosis of mastitis pathogens.

Little information is available about antimicrobial resistance among mastitis pathogens from camel milk. However, Fischer et al. (2013) found that tetracycline resistance was widespread among Strep. agalactiae isolates from camel milk in northern Kenya. Jans et al. (2017) identified Staph. aureus resistance genes in $53 \%$ (30 of 57) of camel milk isolates from Kenya and Somalia. Imprudent use of antimicrobial agents and insufficient hygiene and biosecurity contribute to the emergence and spread of antimicrobial resistance globally (Levy and Marshall, 2004). Monitoring antimicrobial susceptibility in pathogens is of importance for both animal and public health, providing vital information for outreach, advice, and policy recommendations (Acar and Röstel, 2001). Understanding the causative pathogens and risk factors of SCM in pastoralist camel herds is an essential step toward increasing knowledge of the condition. With such knowledge, control efforts can be better adapted, disease prevalence reduced, and pastoralists' livelihoods improved.

This study was carried out around Isiolo town, in Isiolo and Meru Counties, Kenya, with the objectives to investigate the prevalence and risk factors of SCM, IMI, and Strep. agalactiae in milk samples from pastoralist dairy camels in the area, and to assess the CMT as a diagnostic tool for camels in the field. We also wanted to differentiate the species of mastitis bacteria and determine the status of antimicrobial resistance among udder pathogens in pastoralist dairy camels in Isolo County, Kenya.

\section{MATERIALS AND METHODS}

Data were collected through interviews with camel keepers and observations of camel udder and milk status. Milk samples were collected for laboratory analysis as will be described.

\section{Study Area and Population}

Isiolo town is located in Isiolo County, close to the border with Meru County in central Kenya. Isiolo County covers an area of $25,382 \mathrm{~km}^{2}$ (Figure 1). Most parts of the region are classified as very arid, with an average annual rainfall of 150 to $250 \mathrm{~mm}$ (Mati et al., 2005). The 2009 census estimated the camel population in the region to be 39,084 individuals (Kenya National Bureau of Statistics, 2010), distributed over 2,050 camel milk producers (Musinga et al., 2008) out of a total human population of 143,211 individuals in Isiolo County (Munene, 2018). These camels herds are mostly migratory and grazed over large, remote areas, where accessibility to water is limited (Noor et al., 2013).

Camel-keeping households in the area are mainly ethnic Somali, Borana, Garre, Turkana, or Samburu. The camel milk market is expanding in and around the county capital, Isiolo town. An informal milk trade and infrastructure is in place, with milk being transported to the town, where it is refrigerated in bulk, then sold to Nairobi and other parts of the country as well as in local markets. The largest milking cluster and the highest density of camels can be found in and around Isiolo Township, located in Isiolo Central division. Due to the close proximity to Meru County, pastoralist herds regularly cross the county border. However, these herds are regarded as parts of the periurban Isiolo Central milking cluster camel population (Musinga et al., 2008; Noor et al., 2013). The study was carried out from Feb. 
to Apr. 2017, during the end of the dry season and the early wet season.

\section{Sample Selection}

In this cross-sectional study, 20 herds were selected based on a convenience sampling strategy. The geographical distribution of the sampled herds is shown in (Figure 1). Herds eligible for selection had to be managed under pastoralist conditions. Other factors considered during selection of herds were accessibility of herds and willingness to participate and cooperation among animal owners and herders.

\section{Sample Collection}

Before sampling, animal owners and herders were informed about the purpose of the study and the sampling procedures, and their oral consent to take part was obtained. Participants were informed that participation would be anonymous and that they could withdraw from the study at any time if they wished.

Sampling took place during the first morning milking. From each herd, 7 to 13 lactating camels were selected for sampling. In herds with fewer than 20 lactating females, all lactating females were sampled.
In herds with more than 20 lactating females, every second camel was sampled until a target of 10 camels was met. Before sampling, herders were asked whether a milking order existed, to reduce sampling bias. In a few cases, the herders used a milking order based on the age of the calves, with calves divided into different age groups. Under those conditions, equal numbers of camels were randomly selected and sampled from each calf age group.

\section{Interviews}

Individual interviews were conducted with 1 representative of each selected herd, using a structured questionnaire. The questionnaire was pretested on 6 herders in 2 different herds and edited accordingly. The respondent was a person over 18 years old, available at the time of the visit, who had sufficient knowledge of the herd to answer the questions adequately. The interview was implemented by the first author (DS) and the fourth author (WS). The latter is proficient in English, Oromo, Gabbra, and Swahili; he facilitated all contacts with animal owners and performed the interviews. The data were collected digitally on a tablet using free open-source software (KoBo Toolbox, http: //www.kobotoolbox.org/) with the possibility to col-

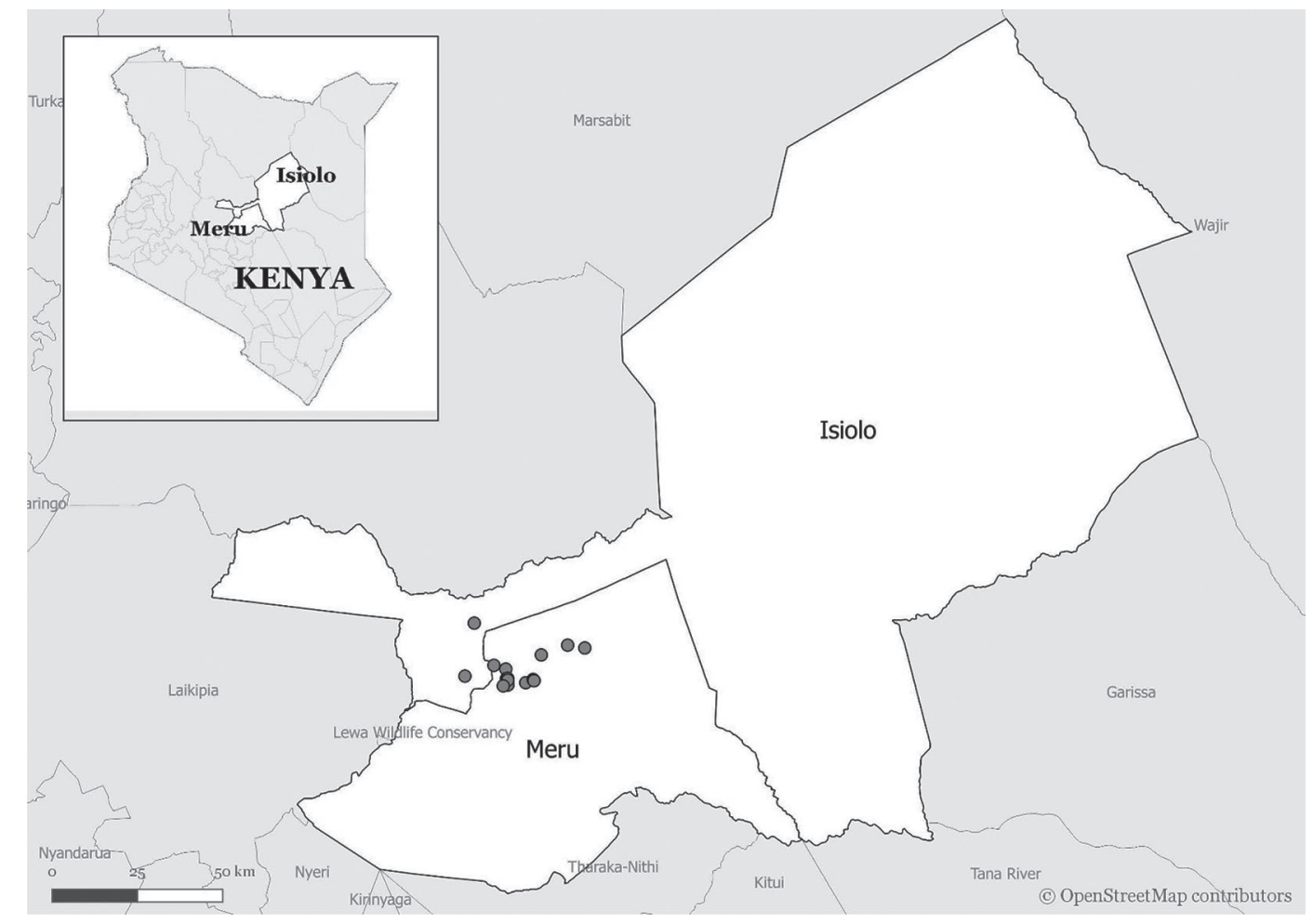

Figure 1. Map of Kenya with Isiolo and Meru counties outlined. The locations of the 20 camel herds participating in the prevalence study of subclinical mastitis are indicated as dots. () OpenStreetMap contributors. Data are available under the Open Database License (https://www. openstreetmap.org) under a CC BY-SA license. 
lect data while off-line. Using this program, data were stored locally and transferred to a cloud-based server as soon as an internet connection was obtained. The questionnaires were constructed and displayed on the tablet in English. Interviews were conducted in Oromo, Gabbra, or Swahili, with translation performed during the interviews and answers noted in English. The questionnaires included individual camel data (age, parity, months in lactation, previous history of mastitis, ongoing treatments, general condition), as well as herd data (herd management and risk factors for subclinical mastitis). The interviews were conducted during or after the sampling. The full questionnaires are displayed in the supplemental materials to this paper (Supplemental Files S1 and S2, https://doi.org/10.3168/jds.2019 -17701).

\section{Clinical Examination and Milk Sampling}

Before sampling, the udder was palpated and checked for blind teats and signs of CM, such as lesions, swelling, heat, pain, induration, and deviating color. Presence of blind teats or signs of CM were recorded on site. Milk let-down was initiated by allowing the calf to suckle. Quarter milk was tested for inflammation using the CMT (Schalm and Noorlander, 1957). After discarding the first streaks of milk, the following approximately $10 \mathrm{~mL}$ of milk per quarter were milked into the CMT paddle. Visual assessment of the milk was performed, with respect to consistency, color, and clots. The milk was then mixed with an equal amount of CMT fluid and blended using a circular motion. Viscosity of the solution was graded according to the Scandinavian scoring system (1 to 5 ), where a score of 1 represents no visible thickening of the fluid, 2 represents mild thickening of the fluid when the vessel is tilted, 3 represents a clear thickening of the fluid, 4 represents increased viscosity and gel formation that dissolves when the vessel is not rotated, and 5 represents the highest viscosity, with a distinct peak formation of the gel (Klastrup and Madsen, 1974). Subclinical mastitis was defined as a test score of $\geq 3$ and the absence of clinical signs of mastitis. Milk samples from all functioning quarters were collected as follows: teats were disinfected using antiseptic wipes, and 1 to 3 streaks of milk were collected into sterile plastic vials and immediately refrigerated using a portable refrigerator (Engel Distribution Pty Ltd., Canning Vale, Australia) connected to a car battery. Milk was frozen at $-18^{\circ} \mathrm{C}$ to $-20^{\circ} \mathrm{C}$ within 2 to $4 \mathrm{~h}$ from the time of sampling.

\section{Bacteriological Analysis}

Laboratory analyses were performed at a commercial accredited laboratory (Analabs Ltd., Nairobi, Kenya) and at the Swedish National Veterinary Institute (SVA, Uppsala, Sweden). Milk samples were transported frozen to the laboratory in Nairobi and stored in a freezer $\left(-20^{\circ} \mathrm{C}\right)$ until culturing. Samples were cultured 1 to $7 \mathrm{~d}$ after the day of sampling. After thawing at room temperature, $10 \mu \mathrm{L}$ of milk was cultured on blood agar (CM0271, Oxoid, Thermo Fisher Scientific, Waltham, MA) and on Edwards agar (Oxoid, CM0027), a culture medium selective for Strep. agalactiae containing 5\% defibrinated sheep blood, and incubated for 24 to $48 \mathrm{~h}$ at $37^{\circ} \mathrm{C}$. Samples with a CMT score $\geq 3$ but displaying negative growth on the primary culture were subjected to extended plating: $40 \mu \mathrm{L}$ of milk was cultured on blood agar and incubated for 24 to $48 \mathrm{~h}$. In addition, $1 \mathrm{~mL}$ of milk was enriched in Todd Hewitt broth for $24 \mathrm{~h}$ at $37^{\circ} \mathrm{C}$, and from the broth $10 \mu \mathrm{L}$ were cultured on Edwards agar and incubated for 24 to $48 \mathrm{~h}$ at $37^{\circ} \mathrm{C}$. Primary identification was based on morphology, catalase test, potassium hydroxide $(\mathrm{KOH})$ test, and Gram staining. Pure culture of $\geq 5$ cfu was recorded as significant. For Strep. agalactiae and Staph. aureus, $\geq 1 \mathrm{cfu}$ was recorded as significant. Samples were classified as contaminated when 3 or more phenotypically different bacterial types were isolated from a milk sample and if growth of a major udder pathogen was not identified. Bacterial isolates were subcultured on blood agar, and pure cultures were inoculated on stab agars that were incubated for 8 to $12 \mathrm{~h}$ at $37^{\circ} \mathrm{C}$ before storage at $4^{\circ} \mathrm{C}$. Stab agars were transported from Analabs to SVA at room temperature for $24 \mathrm{~h}$ and then recultured on blood agar containing $5 \%$ defibrinated horse blood and incubated for 24 to $48 \mathrm{~h}$ at $37^{\circ} \mathrm{C}$. Identification of the isolates was confirmed using MALDI-TOF MS (Bizzini et al., 2010). Bacteria were analyzed in duplicates. Criteria for species identification were as follows: a score of $\geq 2$ indicated identification at species level; 1.80 to 1.99 indicated identification at genus level; and $<1.80$ designated no identification. Species identification was performed using a custom-made database including the Bruker databases no. 5627 and no. 5989 with addition of custom-made spectra (MSP, main spectrum profiles) for some non-aureus species (2 Staphylococcus devriesei, 3 Staphylococcus pseudintermedius, 2 Staphylococcus rostri, 1 Staphylococcus fleurettii, and 1 Staphylococcus lentus).

\section{Susceptibility Testing}

Minimum inhibitory concentrations were determined via broth microdilution, to investigate the antimicrobial susceptibility of the isolates. Testing was performed according to the recommendations of the Clinical and Laboratory Standards Institute (Clinical and Laboratory Standards Institute, 2017) using VetMIC panels 
(SVA) and cation-adjusted Mueller-Hinton broth (Becton Dickinson and Co., Franklin Lakes, NJ). A quality-control strain, Staph. aureus ATCC 15019, was tested in parallel, and the results were within acceptable ranges. The MIC of the following antimicrobial substances were determined: penicillin, cephalothin, oxacillin, erythromycin, chloramphenicol, clindamycin, tetracycline, fusidic acid, gentamicin, kanamycin, ciprofloxacin, and trimethoprim. Cefoxitin was used to detect methicillin-resistant Staph. aureus. Isolates were classified as wild type (absence of phenotypically detectable acquired resistance mechanisms to the agent in question) or non-wild type, based on species-specific epidemiological cutoff (ECOFF) values issued by the European Committee on Antimicrobial Susceptibility Testing (EUCAST, mic.eucast.org). Due to the limited availability of ECOFF for veterinary pathogens, MIC were compared with CLSI clinical break points when ECOFF were lacking.

\section{Statistical Analysis}

Interview data from the KoBo Toolbox were transferred to Excel (Microsoft Corp., Redmond, WA) for data editing. Descriptive statistics were used to summarize, at udder quarter level, the distribution of CMT scores, bacteriological findings, and results from the clinical examination, as well as the distribution of antimicrobial resistance among the bacterial isolates. The distribution of IMI and CMT scores was summarized at camel and herd level for parity $(1,2,3,4,5, \geq 6)$, age $(<7,7$ to 8,9 to $10, \geq 11 \mathrm{yr})$, months in lactation $(1,2$, 3,4 to 8,9 to 12,13 to $19, \geq 20 \mathrm{mo}$ ), and all variables in the questionnaires. Associations between SCM (yes/ no), as well as IMI (yes/no) and Strep. agalactiae (yes/ no; dependent variables) in udder quarter milk samples, summarized to camel level, and breed, parity, age, month in lactation, and all variables in the questionnaires (independent variables), were investigated using univariable mixed-effect logistic regression analyses. Herd was included as a random factor, taking into account that camels in the same herd are more similar than camels in different herds. An independent covariance structure was used for the random effect. Before analysis, continuous independent variables were assessed if they were linearly related to the outcome by visual examination (using the lowess command in Stata; Stata Statistical Software, release 13.1; StataCorp LP, College Station, TX). If variables did not seem to be linearly related, they were categorized using percentiles as cutoffs. In all multivariable models, a manual, stepwise-backward variable selection procedure was used, in which the initial model included all independent variables as main effects. Collinearity between the independent variables was assessed pairwise by Spearman rank correlations. If proof of collinearity $(r \geq 0.70)$ was present, the variable with the lowest $P$-value in the univariable analysis was selected. All plausible 2-way interactions between the significant main effects were tested. Variables with a significant association with the dependent variable $(P$ $<0.05)$ were kept in the model. In the final analysis, the variables SCM, IMI, and Strep. agalactiae, when used as independent variables, were excluded from respective models because their strong collinearity was obscuring other potential relations with the main effects. Diagnostic plots were visually examined to assess the model fit of the multivariable analyses, according to Dohoo et al. (2009). Data were managed, analyzed, and visualized using Stata.

\section{RESULTS}

\section{Study Population}

A total of 20 herds were visited, and 206 animals were sampled. Most of the visited herds kept camels of the Somali breed (13 of 20 herds); the remaining herds consisted mainly of Gabra breed or Somali crossbreeds. Reported herd sizes ranged from 21 to 200 animals, and the number of lactating animals within each herd ranged from 7 to 52 camels. Median age of the included camels was 9 yr [interquartile range (IQR) 7 to 11], median parity was 3 (IQR 2 to 5 ), and median months in lactation was 5 (IQR 3 to 12).

\section{Herd Management}

All herds were managed under pastoralist conditions and migrated depending on available pasture, directly affecting the changing frequency of the boma (traditional enclosure constructed from bushes and branches, where the camels are kept overnight and during milking). All the interviewed participants sold camel milk to markets, to middlemen, or directly to hotels in Isiolo town. In most herds (17 of 20), camels were given commercially available minerals for livestock as supplement to their feed; hay was given as supplement in 1 herd.

\section{Milking Routine}

In all herds, lactating dams and calves were separated overnight. During milking, calves were released one by one and allowed to suckle their mothers to initiate milk let-down. All camels were hand-milked by male herders, with milking being carried out by 2 milkers simultaneously, 1 from each side. In $75 \%$ of the herds (15 of 20), camels were milked twice a day; the remaining herds milked their camels only once a day. 
One of these herds reported milking their camels once a day only during dry season; however, the milking frequency during the wet season was not specified. In 8 of the herds, a milking order was used: in 4 herds, newly-calved camels were milked first; in 3 herds, the youngest camels were milked first; and the remaining herd used a different system, where some camels would be milked without prior stimulation by the calf and different camels were milked once or twice a day. In half of the herds, the milkers reported that they would always wash their hands with water before milking, and in 5 herds, the milkers would sometimes wash their hands with water before milking. Another 3 herds reported that the milkers would always wash their hands before milking, using both soap and water. In the remaining 2 herds, the milkers did not sanitize their hands before milking. During the herd visits, the authors did not observe hand-washing take place on any single occasion. Only 1 herd reported cleaning of udders or teats before milking. No post-milking teat disinfection was practiced in any of the herds.

\section{Experiences and Treatment of Mastitis}

All herds had experience of CM and reported observations of symptoms as follows: pain (100\%), swelling $(100 \%)$, fever $(95 \%)$, reduced milk production $(90 \%)$, changes in milk consistency (85\%), induration of udder tissue $(75 \%)$, changes in milk color $(45 \%)$, and redness of udder quarter (5\%). Most participants (17 of 20) reported that they would treat clinical cases of mastitis with antibiotics (route of administration was not specified; however, this is likely to represent parenteral application), whereas 1 herd reported that they also used traditional remedies. The type of traditional remedy was not stated. Moreover, 4 herds would abstain from milking camels with clinical signs of mastitis. In 3 herds, milk from camels with CM would be separated from the pooled bulk milk. Few herds (4 of 20) had used veterinary services during the previous year, and a very limited access to animal health professionals was often cited as a constraint to improved milk production. However, antibiotics were reported to have been used in all herds within the last year. A combination of streptomycin and penicillin had been used by $100 \%$ (20 of 20) of the respondents; the second most common substance was oxytetracycline, used by $60 \%$ (12 of 20) of the respondents. Only 1 herd reported having used unalloyed penicillin

\section{Clinical Examination}

In all, $2 \%$ (17 of 804) of the udder quarters in 5\% (11 of 206) of the camels displayed symptoms of acute clini- cal mastitis (changes in milk, swelling, pain) in combination with a CMT score $\geq 3$. Furthermore, $4 \%$ (28 of 804 ) of the udder quarters in $10 \%$ (20 of 206) of the camels were diagnosed with chronic clinical mastitis, defined as palpatory findings (induration of udder tissue) combined with an elevated cell count (CMT score $\geq 3$ ). Half of the camels (14 of 28) with chronic CM in at least 1 quarter also had SCM in at least 1 quarter. However, 5\% (10 of 206) of the camels had palpatory findings in the udder tissue in combination with a low CMT score $(<3)$. Blind teats or skin lesions on udder or teats were present in 6\% (13 of 206) and 9\% (18 of 206) of the camels, respectively. Teat tying was recorded for 7 camels ( 7 of 206, 3\%), and tick infestation was observed in 28 camels ( 28 of $206,14 \%$ ). In total, $11 \%$ (22 of 206) of the camels were reported to have had CM previously.

\section{Subclinical Mastitis}

Milk from a total of 804 udder quarters was collected from the 206 camels and scored using CMT. Subclinical mastitis, defined as a CMT score $\geq 3$ and absence of clinical signs of mastitis, was present in $26 \%$ (207 of 804 ) of the sampled quarters. In total, $46 \%$ (95 of 206) of the sampled camels had 1 or more quarters with SCM, and in all herds at least 1 camel presented with SCM. The average within-herd prevalence was $46 \%$ (median 45\%, IQR 30 to 55\%). Most of the camels with SCM (45 of 95, 47\%) had only 1 affected quarter, whereas $22 \%$ (21 of 95 ) of the camels were diagnosed with SCM in 2 quarters, 25\% (24 of 95) had 3 quarters affected, and 13\% (12 of 95) had SCM in all 4 quarters.

\section{Bacterial Analysis and Intramammary Infection}

Milk samples from 798 udder quarters were collected, cultured, and analyzed. We found IMI in 1 or more quarters in $64 \%$ (93 of 145) of the camels and in $33 \%$ (215 of 798) of all quarters. In all herds at least 1 camel had IMI. Whether IMI was present or not could not be determined in 61 of the sampled camels, due to mixed bacterial growth in at least 1 sample (56 camels) or incomplete sampling (5 camels). Among IMI-positive camels, 31\% (29 of 93) had 1 infected quarter, 26\% (24 of 93) had 2 infected quarters, $25 \%$ (23 of 93) had 3 infected quarters, and 18\% (17 of 93) had all 4 quarters infected. To correctly identify quarters with IMI, the sensitivity and specificity for CMT when using CMT $<3$ and CMT $>3$ as cutoff were $82 \%$ and $92 \%$, respectively (95\% CI: 0.84 to 0.90$)$.

The distribution of udder pathogens is presented in Table 1 . The most commonly isolated udder pathogen was Strep. agalactiae. In all, Strep. agalactiae was 
Table 1. Distribution of udder pathogens and spread of California Mastitis Test (CMT) scores in 798 quarter milk samples from 206 camels in 20 pastoralist herds around Isiolo town, Kenya, sampled Feb. to Apr. 2017

\begin{tabular}{|c|c|c|c|c|c|c|}
\hline \multirow[b]{2}{*}{ Bacteria $^{1}$} & \multirow[b]{2}{*}{ No. $(\%)^{2}$} & \multicolumn{5}{|c|}{ CMT score $^{3}$} \\
\hline & & 1 & 2 & 3 & 4 & 5 \\
\hline Streptococcus agalactiae & $137(17.2)$ & 6 & 13 & 29 & 46 & 43 \\
\hline Staphylococcus aureus & $18(2.3)$ & 2 & 4 & 5 & 4 & 3 \\
\hline Staphylococcus chromogenes & $5(0.6)$ & 0 & 1 & 3 & 0 & 1 \\
\hline Staphylococcus delphini & $2(0.3)$ & 0 & 1 & 0 & 1 & 0 \\
\hline Staphylococcus epidermidis & $1(0.1)$ & 0 & 0 & 1 & 0 & 0 \\
\hline Staphylococcus haemolyticus & $1(0.1)$ & 0 & 1 & 0 & 0 & 0 \\
\hline Staphylococcus hyicus & $2(0.3)$ & 0 & 0 & 1 & 1 & 0 \\
\hline Staphylococcus rostri & $5(0.6)$ & 0 & 2 & 1 & 2 & 0 \\
\hline Staphylococcus simulans & $12(1.5)$ & 0 & 1 & 5 & 1 & 5 \\
\hline Combination flora $^{4}$ & $19(2.4)$ & 0 & 0 & 7 & 2 & 10 \\
\hline Strep. agalactiae + Staph. aureus $s^{5,6}$ & $10(1.3)$ & 0 & 0 & 1 & 1 & 8 \\
\hline Strep. agalactiae $+\mathrm{NAS}^{6}$ & $7(0.9)$ & 0 & 0 & 4 & 1 & 2 \\
\hline Combination of $\mathrm{NAS}^{7,8}$ & $2(0.3)$ & 0 & 0 & 2 & 0 & 0 \\
\hline Arthrobacter ilicis & $1(0.1)$ & 0 & 1 & 0 & 0 & 0 \\
\hline Streptococcus gallolyticus & $1(0.1)$ & 0 & 1 & 0 & 0 & 0 \\
\hline Unidentified $^{8}$ & $11(1.4)$ & 4 & 2 & 5 & 0 & 0 \\
\hline Contaminated & $136(17.0)$ & 49 & 53 & 24 & 6 & 4 \\
\hline No growth & $447(56.0)$ & 196 & 212 & 25 & 9 & 5 \\
\hline Total & $798(100.0)$ & 257 & 292 & 106 & 72 & 71 \\
\hline
\end{tabular}

${ }^{1}$ Pure culture was defined as $\geq 5$ cfu of 1 bacterial species, with the exception of findings of Strep. agalactiae and Staph. aureus, where $\geq 1$ cfu was considered pure culture. Samples were classified as contaminated when 3 or more phenotypically different bacterial types were isolated from a milk sample and if growth of a major udder pathogen was not identified.

${ }^{2}$ Proportions presented are based on the total number of milk samples.

${ }^{3} \mathrm{CMT}$ score based on the Scandinavian 1 to 5 scale, where 1 represents the most fluid result and 5 represents a coagulated mass with a distinct peak formation.

${ }^{4}$ Samples yielding more than 1 udder pathogen are presented as combination flora.

${ }^{5}$ One sample included a combination of Strep. agalactiae, Staph. aureus, and Staph. simulans.

${ }^{6}$ Included in the combination flora group.

${ }^{7}$ Represents 1 combination of Staph. epidermidis and Staphylococcus warneri, and 1 combination of Staph. epidermidis and Staph. simulans.

${ }^{8}$ Represents isolates either not reaching sufficient score values for secure identification on species level or not identified by MALDI-TOF MS. At the genus level, 3 isolates were identified as Staphylococcus spp., and 1 isolate was identified as Streptococcus spp.; the remaining isolates were not recognized.

isolated from $72 \%$ (154 of 215) of the IMI-positive quarters, giving a prevalence of $19 \%$ (154 of 798) at quarter level, $32 \%$ (65 of 206) at camel level, and a herd prevalence of $95 \%$ (19 of 20). The second most commonly isolated bacteria were NAS, found in $19 \%$ (41 of 215 ) of the IMI-positive quarters and in $75 \%$ (15 of 20) of the herds. Of the NAS, Staphylococcus simulans was isolated from 16 samples, Staphylococcus delphini was isolated in 6 samples, Staph. rostri and Staphylococcus chromogenes were each isolated from 5 samples, Staphylococcus hyicus was isolated from 2 samples, and Staphylococcus haemolyticus and Staphylococcus warneri were each isolated from 1 sample. The third most commonly isolated udder pathogen was Staph. aureus, found in $13 \%$ (28 of 215) of IMI-positive quarters and in $70 \%$ (14 of 20) of the herds. Co-infection with Staph. aureus and Strep. agalactiae was confirmed in 10 samples.

We found conclusive growth of 1 bacterial species in $25 \%$ (196 of 798 ) of the samples, $17(2 \%)$ of the samples yielded growth of 2 udder pathogens, and 3 udder pathogens were found in 1 sample $(<0.1 \%)$. The distribution of udder pathogens in relationship to mastitis diagnosis is shown in Table 2.

\section{Antimicrobial Susceptibility Testing}

In all, 210 isolates from 81 camels and 192 udder quarters from 3 different species groups, Strep. agalactiae $(\mathrm{n}=142)$, Staph. aureus $(\mathrm{n}=27)$, and NAS $(\mathrm{n}=$ 41), were randomly selected and tested for antimicrobial susceptibility. The MIC for penicillin, cephalothin, chloramphenicol, ciprofloxacin, clindamycin, erythromycin, gentamicin, tetracycline, and trimethoprim are shown in Table 3.

Among the Strep. agalactiae isolates, 6 out of 142 $(4.9 \%)$ displayed growth at concentrations below the given ECOFF for tetracycline, whereas the majority (137 of $142,95.1 \%$ ) displayed MIC well above the 
ECOFF. In contrast, for penicillin, all isolates grew at MIC lower than the ECOFF. For both clindamycin and ciprofloxacin, all the tested Strep. agalactiae isolates had MIC below the ECOFF, and the wild-type rates for erythromycin were similar (141 of 142, 99.3\%). For cephalothin, a comparison with the clinical breakpoint for susceptibility (MIC $\leq 2.0 \mu \mathrm{g} / \mathrm{mL}$; cutoff calculated for $\beta$-hemolytic streptococci infections of skin and soft tissue in dogs) verifies that all isolates had a MIC value below this value. For chloramphenicol, all isolates $(\mathrm{n}=$ 142) had MIC below the available clinical breakpoint for susceptibility (defined as MIC $\leq 4 \mu \mathrm{g} / \mathrm{mL}$, based on human streptococci isolates in soft tissue). For trimethoprim and gentamicin, no ECOFF or clinical breakpoints were available for comparison; however, their MIC were normally distributed.

The wild type of Staph. aureus was common: 24 out of 27 isolates $(88.9 \%)$ had tetracycline MIC below the ECOFF, whereas for penicillin 16 out of 27 $(59.1 \%)$ of the isolates displayed growth at concentra- tions lower than the ECOFF. For cephalothin and gentamicin, $96.3 \%$ (26 of 27) of the isolates had MIC below the ECOFF. For chloramphenicol, ciprofloxacin, clindamycin, erythromycin, and trimethoprim, all isolates displayed growth at concentrations lower than the ECOFF. In addition, all tested Staph. aureus isolates were susceptible to cefoxitin (MIC $>4 \mu \mathrm{g} / \mathrm{mL}$ ); thus, we did not further investigate methicillin resistance.

For NAS species, 37 out of $41(90.3 \%)$ of the tested isolates had MIC below the ECOFF for tetracycline. In all, 27 out of 41 isolates (65.9\%) were classified as susceptible to penicillin according to the CLSI breakpoints for Staphylococcus spp. (MIC $\geq 0.12 \mu \mathrm{g} / \mathrm{mL}$, as determined in humans). Furthermore, all NAS isolates tested against chloramphenicol and erythromycin displayed MIC below the set ECOFF. For clindamycin and gentamicin, the proportions of isolates with MIC below the ECOFF were $93.2 \%$ (37 of 41 ) and $97.6 \%$ (40 of 41) respectively. No cutoffs were available for cephalothin or ciprofloxacin, and the MIC were nor-

Table 2. Number of udder quarters diagnosed with $\mathrm{IMI}^{1}$ and distribution of udder pathogens isolated from 798 udder quarters diagnosed with either subclinical mastitis (SCM), ${ }^{2}$ acute clinical mastitis $(\mathrm{ACM}),{ }^{3}$ or chronic clinical mastitis $(\mathrm{CCM})^{4}$ in 206 dairy camels in Isiolo, Kenya

\begin{tabular}{lrrrr}
\hline Item & SCM & ACM $^{5}$ & CCM & CMT score $<3$ \\
\hline IMI & $144^{6}$ & $14^{7}$ & $18^{8}$ & 39 \\
Positive & 31 & $1^{9}$ & 8 & 407 \\
Negative & 106 & 12 & 17 & 19 \\
Streptococcus agalactiae & 20 & 1 & 1 & 6 \\
Staphylococcus aureus & 30 & 3 & 1 & 1 \\
NAS ${ }^{10}$ & 14 & 1 & 0 & 1 \\
Staphylococcus simulans & 3 & 1 & 1 & 1 \\
Staphylococcus delphini & 3 & 1 & 0 & 0 \\
Staphylococcus chromogenes & 4 & 0 & 0 & 2 \\
Staphylococcus epidermidis & 2 & 0 & 0 & 1 \\
Staphylococcus hyicus & 3 & 0 & 0 & 0 \\
Staphylococcus rostri & 0 & 0 & 0 & 1 \\
Staphylococcus haemolyticus & 1 & 0 & 0 & $6^{11}$ \\
Staphylococcus warneri & 0 & 0 & 0 & 102 \\
Arthrobacter ilicis & 0 & 0 & 0 & 407 \\
Streptococcus gallolyticus & 5 & 0 & 0 & 2 \\
Unidentified & 32 & 0 & 2 & 0 \\
Contaminated & 31 & 1 & 8 & \\
No growth & 5 & 0 &
\end{tabular}

${ }^{1}$ IMI defined as growth of $\geq 5$ cfu of 1 bacterial species, with the exception of findings of Streptococcus agalactiae and Staphylococcus aureus, for which $\geq 1$ cfu was considered significant growth. Quarters with inconclusive growth $(\mathrm{n}=136)$ are excluded.

${ }^{2} \mathrm{SCM}$ defined as California Mastitis Test (CMT) score $\geq 3$ (scale 1 to 5 , where 1 represents the most fluid result and 5 represents a coagulated mass with distinct peak formation) and no clinical mastitis symptoms.

${ }^{3} \mathrm{ACM}$ defined as at least 1 of the following symptoms: changes in the milk, swollen quarter, udder pain.

${ }^{4} \mathrm{CCM}$ defined as findings of induration in the udder tissue in combination with CMT score $\geq 3$.

${ }^{5}$ Milk samples missing for 2 quarters.

${ }^{6} 15$ samples yielding combination of 2 species; 1 sample yielding a combination of 3 species.

${ }^{7} 2$ samples yielding combination of 2 species.

${ }^{8} 1$ sample yielding combination of 2 species.

${ }^{9}$ Represents 1 udder quarter with swelling and CMT score 2.

${ }^{10}$ Includes isolates not reaching sufficient scores for secure identification at species level by MALDI-TOF MS.

${ }^{11}$ Includes 2 isolates identified as staphylocci at genus level. 
Table 3. Distribution of MIC of 10 antimicrobial agents for Streptococcus agalactiae $(\mathrm{n}=142)$, Staphylococcus aureus $(\mathrm{n}=27)$, and NAS ( $\mathrm{n}=$ 41) isolated from cases of subclinical mastitis in dromedary camels from a field study conducted Feb. to Apr. 2017 around Isiolo town, Kenya ${ }^{1}$

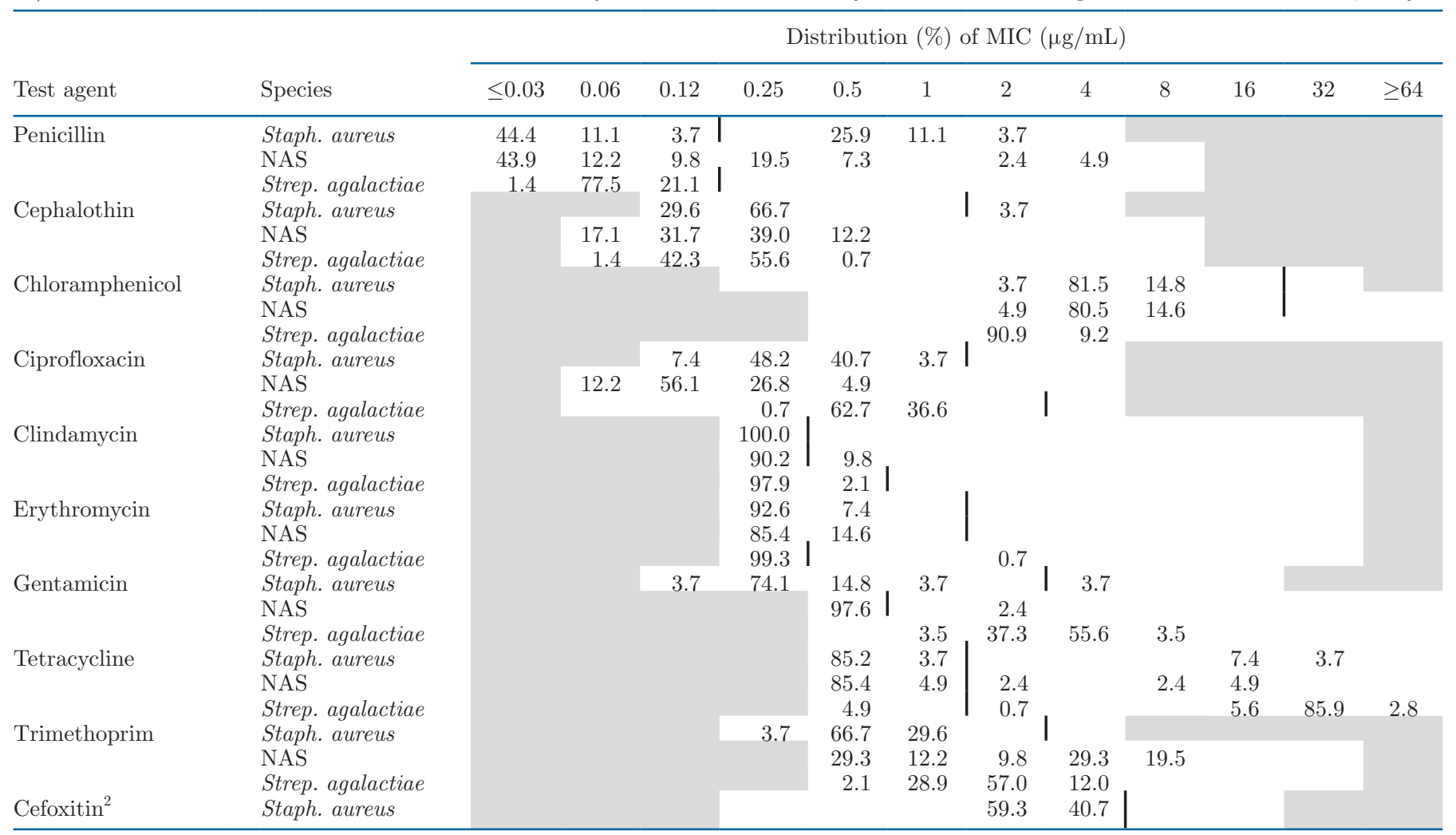

${ }^{1}$ Shaded cells indicate concentrations outside the range tested for the given antimicrobial. Blank unshaded cells indicate no isolates with a MIC at that concentration. For MIC equal to or lower than the lowest concentration tested for an antimicrobial $(\leq \mathrm{Y} \mu \mathrm{g} / \mathrm{mL})$ the percentage is given as the lowest tested concentration (i.e., in the leftmost cell of the tested range). Vertical lines indicate epidemiological cutoff values issued by the European Committee on Antimicrobial Susceptibility Testing.

${ }^{2}$ Only tested for Staph. aureus.

mally distributed. A bimodial distribution of MIC of trimethoprim was observed, which is consistent with the wild-type MIC pattern.

\section{Risk Factor Analyses}

Risk Factors Associated with SCM. In total, 146 camels from 19 herds were included in the univariable analysis for SCM; 10 animals were excluded from the analysis due to missing data. Camels with CM and camels with palpatory findings in at least 1 udder quarter were excluded from the risk factor analysis. Subclinical mastitis was significantly associated with IMI $(P<0.001)$ and with Strep. agalactiae findings $(P$ $<0.001)$. Moreover, age $(P<0.001)$ and number of months in lactation $(P=0.001)$ were risk factors for SCM. Older camels ( $>9$ years) and camels in mid- to late lactation ( $\geq 5 \mathrm{mo}$ ) had higher odds of having SCM than younger camels and camels in early lactation. Skin lesions on the teats or udder were associated with SCM $(P=0.04)$ (Supplemental Tables S1 and S2; https: //doi.org/10.3168/jds.2019-17701). Of the 10 variables included in the univariable analysis, 6 had a $P$-value of $\leq 0.20$ and were further analyzed in the multivariable model. In the final multivariable mixed-effect logistic regression model, only lactation length remained significant $(P=0.001)$. Collinearity was found between the variables age and parity; thus, parity was excluded due to a higher $P$-value in the univariable analysis. The odds of SCM were lower in early lactation, both for camels in first or second month of lactation [odds ratio $(\mathbf{O R})=0.08, P<0.001]$ and for camels in third or fourth month of lactation (OR $=0.15, P=0.001)$ compared with camels in mo 12 to 23 of lactation. This difference was also seen between camels in first or second month of lactation ( $\mathrm{OR}=0.31, P=0.05)$ compared with camels in mo 5 to 11 of lactation. The random effect of herd was not significant in the final model $(P$ $=0.13$ ); hence, ordinary logistic regression was applied. The model showed good fit to the data.

Risk Factors Associated with IMI. In the univariable analysis, we found that IMI was associated 
Table 4. Multivariable mixed-effects logistic regression, including herd as a random factor, investigating associations between potential risk factors and presence of intramammary infection caused by Streptococcus agalactiae, defined as growth of $\geq 1$ cfu of Strep. agalactiae in milk samples from 196 dromedary camels in 20 pastoralist herds around Isiolo town, Kenya

\begin{tabular}{|c|c|c|c|c|c|}
\hline Variable and category & $\beta^{1}$ & $\mathrm{SE}^{\beta}$ & $\mathrm{OR}^{2}$ & $95 \%$ CI (OR) & $P$-value \\
\hline \multicolumn{5}{|l|}{$\mathrm{Age}^{3}$} & $<0.001$ \\
\hline$<7$ years & -3.11 & 0.77 & 0.04 & $0.01-0.20$ & $<0.001$ \\
\hline 7 to 8 years & -2.00 & 0.55 & 0.14 & $0.05-0.41$ & $<0.001$ \\
\hline 9 to 11 years & -1.52 & 0.55 & 0.22 & $0.07-0.65$ & 0.006 \\
\hline$>11$ years & Referent & & & & \\
\hline \multicolumn{6}{|c|}{ Previous history of mastitis ${ }^{3}$} \\
\hline Yes & 2.51 & 0.80 & 12.3 & $2.57-59.1$ & 0.002 \\
\hline No & Referent & & & & \\
\hline \multicolumn{6}{|c|}{ Having at least 1 blind teat } \\
\hline Yes & 1.66 & 0.84 & 5.28 & $1.02-27.3$ & 0.05 \\
\hline No & Referent & & & & \\
\hline
\end{tabular}

${ }^{1} \beta=$ regression coefficient.

${ }^{2} \mathrm{OR}=$ odds ratio.

${ }^{3}$ As reported by the animal owner or herder.

with SCM $(P<0.001)$, parity $(P=0.06)$, and age $(P<0.001)$. We found a linear increase in risk with higher parity and age. Furthermore, having had CM previously significantly increased the risk of IMI $(P=$ 0.03; Supplemental Table S2, https://doi.org/10.3168/ jds.2019-17701). Of the 10 variables investigated in the univariable analysis, 6 had a $P$-value $\leq 0.20$ and were included in the multivariable analysis. Collinearity was found between the variables age and parity, and because age had a lower $P$-value in the univariable analysis, age was kept in the model. In the final multivariable mixed-effects logistic regression model, the only remaining variable was age, showing a positive association between IMI and camels older than 7 yr $(P<$ $0.001)$. Camels 7 to 8 yr $(\mathrm{OR}=3.5, P=0.04), 9$ to 10 yr $(\mathrm{OR}=5.0, P=0.01)$, and older than 11 years $(\mathrm{OR}$ $=20.2, P<0.001)$ were more likely to have IMI than camels younger than $7 \mathrm{yr}$. The difference was also seen when comparing camels older than $11 \mathrm{yr}$ to camels aged 7 to 8 yr $(\mathrm{OR}=5.8, P=0.005)$ and 9 to $10 \mathrm{yr}(\mathrm{OR}=$ 4.0, $P=0.04)$ but not when comparing the age groups 7 to 8 and 9 to 10 years $(\mathrm{OR}=0.70, P=0.52)$. The random effect of herd was not significant in the final model $(P=0.23)$; hence, ordinary logistic regression was applied. The model showed good fit to the data.

Risk Factors Associated with Str. agalactiae. The most commonly isolated udder pathogen was Strep. agalactiae, and we investigated potential risk factors for IMI caused by Strep. agalactiae. Similar to the risk factors for IMI, an association between SCM and Strep. agalactiae $(P<0.001)$, as well as parity $(P<$ $0.001)$ and age $(P<0.001)$ was seen. Previous history of clinical mastitis $(P=0.001)$ and palpatory findings in the udder $(P=0.06)$ were associated with isolation of Strep. agalactiae in milk. Camels positive for Strep. agalactiae-associated IMI were more likely to have at least 1 blind teat $(P=0.02)$ than were healthy camels and camels with IMI caused by other udder pathogens (Supplemental Table S2, https://doi.org/10.3168/jds .2019-17701). Out of a total of 7 variables included in the multivariable analysis, 3 remained in the final model. We found collinearity between the variables age and parity, and, subsequently, only the variable age was kept in the model, because age had a lower $P$-value in the univariable analysis. The risk for Strep. agalactiae was higher with increasing age $(P<0.001)$; risk was significantly higher for camels older than 11 yr compared with all other age groups, as shown in Table 4 . The risk was also significant when comparing camels aged 9 to $10 \mathrm{yr}(\mathrm{OR}=4.9, P=0.04)$ with camels younger than 7 yr. Furthermore, camels aged 9 to 10 yr had higher odds of having Strep. agalactiae IMI than did camels younger than $7 \mathrm{yr}(\mathrm{OR}=0.20, P=0.04)$; the risk was also significant when compared with camels older than $11 \mathrm{yr}(\mathrm{OR}=4.6, P=0.006)$. In addition, anecdotal information about previous CM episodes in the individual camel $(\mathrm{OR}=12.3, P=0.001)$, as well as having at least 1 blind teat $(\mathrm{OR}=5.28, P=0.049)$, were positively associated with isolation of Strep. agalactiae (Table 4). The random effect of the herd was significant in the final model $(P<0.001)$. Residual plots were assessed, and the model showed good fit to the data.

\section{DISCUSSION}

In the present study, we found a high prevalence of SCM at quarter, individual, and herd levels, consistent with other studies (Aljumaah et al., 2011; Kashongwe et al., 2017). Increasing age and stage of lactation were both associated with a higher risk of SCM as well as 
with higher risk of IMI and findings of Strep. agalactiae IMI. Other studies conducted under similar conditions show diverging results regarding risk factors for SCM: in a study by Regassa et al. (2013), SCM was associated with early lactation, whereas in studies by Abdurahman et al. (1995) and Ahmad et al. (2012), the risk increased with age, parity, and stage of lactation. Because camels naturally have a long lactation (up to 24 mo; Bekele et al., 2011; Nagy and Juhasz, 2016), a later lactation stage means a longer time of exposure to udder pathogens, and thus higher accumulated risk. Furthermore, SCM was associated with skin lesions on the teats and udder, conditions that can accumulate over time. Lesions can serve as a reservoir for bacterial populations, and impaired sphincter mechanisms due to lesions can contribute to the establishment of SCM and IMI (Agger and Willeberg, 1986; Dingwell et al., 2004). Tick infestation of the udder and the use of anti-suckling devices (teat tying) have been found to increase the risk of contracting SCM in dromedaries (Abdurahman et al., 1995; Obied et al., 1996; Ahmad et al., 2012). In the present study, tick infestation was not a risk factor for SCM, and the number of observations of anti-suckling devices was low compared with other studies in the region (Regassa et al., 2013). Due to sampling and observation taking place concurrently with the rapid milking process, with one camel being prepared for milking while the previous camel is still being milked, it is possible that the number of observed cases of teat tying in this study is an underrepresentation of the true figure. The calculated SCM prevalence, however, was not lower than in studies where these risk factors were significant. Thus, it cannot be ruled out in this study that teat tying may be a contributing factor to the occurrence of the disease. Streptococcus agalacti$a e$ was the most prevalent finding in milk samples from camels with SCM, as well as in cases of CM observed in our study, which is supported by present knowledge of mastitis-causing agents in the region. Prevalence of Strep. agalactiae in dairy camels has been reported at $27 \%$ at quarter level in Ethiopia (Obied et al., 1996) and at 10 to $12 \%$ at camel level in Kenya (Younan et al., 2001; Toroitich et al., 2017). The presence of blind teats, induration of udder tissue, and anecdotal information about previous cases of $\mathrm{CM}$ in the camel were associated with findings of Strep. agalactiae in at least 1 udder quarter. This suggests that IMI caused by Strep. agalactiae is likely to develop into a chronic condition in camels (Schalm and Mead, 1943; Ramadan et al., 1987; Wyder et al., 2011). Little is known about the transmission and epidemiology of mastitis caused by Strep. agalactiae in dairy camels. In other species, Strep. agalactiae is considered a contagious udder pathogen that can be transmitted within herds through contaminated milking equipment and compromised milking hygiene (Dargent-Molina et al., 1988; Bartlett et al., 1992; Kotb et al., 2010). The absence of acceptable hygiene standards for milking offers one possible explanation for the spread and circulation of Strep. agalactiae within camel herds. Although the majority of the participants in this study reportedly washed their hands before milking, this was never observed by the authors and could represent social desirability bias. Furthermore, the hygienic quality of water available for washing is generally low (Wang et al., 2014). For dairy cows, Strep. agalactiae is commonly introduced into herds through the purchase of infected animals (Agger et al., 1994). In this study, we did not collect data on introduction of new animals in the herds. Nevertheless, lactating camels are rarely bought from other herds, due to their high market value and the prevailing judgement among pastoralists that only faulty breeding females would be offered for sale (Noor et al., 2013). However, camel herds are not closed herds. Regular transfer of female camels occurs between different herds in relation to their reproductive state, and camel herds are commonly kept together with other livestock. In a study by Younan and Bornstein (2007), Strep agalactiae was isolated from the nasopharynx and the vaginal mucosa of apparently healthy camels. This suggests that Strep. agalactiae could be maintained in camel herds through normal flora rather than being introduced via entry of new animals. In a study in dairy cows in Norway, Jørgensen et al. (2016) isolated Strep. agalactiae from environmental reservoirs as well as from extramammary sites, suggesting that Strep. agalactiae might not be an obligate intramammary pathogen and offering a model for a more complex transmission cycle than previously acknowledged. The molecular epidemiology of Strep. agalactiae, including non-udder-associated strains in bovines, is further described in a study of Colombian dairy cows (CoboÁngel et al., 2018) that reported bovine fecal shedding of Strep. agalactiae. Environmental reservoirs are not likely to play a fundamental part in the transmission of Strep. agalactiae within camel herds on pasture. Unlike commercial large-scale bovine dairy herds, camels are grazed over vast areas, the environment is dry, and visible fecal contamination of udders, bedding, and milking equipment is slight. So far, there is no conclusive understanding on the potential cross-species transmission of Strep. agalactiae between humans and camels. Fischer et al. (2013) found that Strep. agalactiae in camels belonged to a distinct sequence type separate from human sequence types. Nevertheless, the relationship between human and camel Strep. agalactiae strains in pastoralist communities, where humans and animals 
are in close contact and where raw milk consumption is common practice, should be investigated and the transmission routes of Strep. agalactiae studied in detail.

In the present study, the prevalence of NAS was similar to that found in previous reports from the region (Matofari et al., 2005; Husein et al., 2013). Because NAS are commonly found on teat skin (Adkins et al., 2018), it is difficult to assess whether NAS findings in milk samples yielding mixed growth should be considered significant or contamination; thus we cannot exclude the idea that the true number of NAS-derived cases of IMI in this study may be higher than what we report.

We found a strong association between SCM and the presence of IMI. The sensitivity and specificity of CMT as an instrument for identifying IMI were $82 \%$ and $92 \%$ respectively, similar to previous results for camel milk (Abdurahman et al., 1995; Younan et al., 2001). Thus, CMT is an easy-to-use and efficient diagnostic tool that could be used for monitoring SCM in camel herds as a control measure to detect IMI-positive camels. Nevertheless, some udder quarters with high CMT scores displayed negative growth. The absence of bacteria on culturing could be attributed to aseptic chronic mastitis, to non-shedding of bacteria at the time of sampling, to IMI in remission (Taponen et al., 2009), or to fluctuating SCC due to physiological and environmental factors (Nagy et al., 2013). Furthermore, recovery of bacteria from milk samples could be affected by the freezing process before culturing (Schukken et al., 1989).

Unregulated use of antimicrobial agents was frequently reported in this study, and tetracyclines were commonly used to treat different types of disease in camels. In a previous study on use of antimicrobials among camel pastoralists in Isiolo by Lamuka et al. (2017), $46 \%$ of the participants reported using tetracyclines routinely. Systemic use of antimicrobials without appropriate dose regimens could explain the high levels of resistance to tetracyclines seen in pathogens isolated from camels in the region (Fischer et al., 2013; Jans et al., 2017; Mutua et al., 2017). In the present study, we did not classify isolates as resistant or not, due to the low availability of such breakpoints for mastitis-causing pathogens. However, the high proportion of Strep. agalactiae isolates displaying growth at MIC higher than the ECOFF indicates acquired resistance in the isolates (non-wild type). The assessment of antimicrobial resistance patterns in this study is limited to phenotypic testing and does not provide information about resistance genes. The scientific basis for pharmacokinetics and pharmacodynamics of antimicrobials in camels, with special reference to therapeutic use against mastitis, is scanty (Ali et al., 1996; Barlow, 2011). Limited knowledge on withdrawal times for antimicrobials is likely to result in residues in milk, which could further contribute to the spread of antimicrobial resistance among milk consumers.

Participants in the present study did not frequently mention mastitis as an important disease in milk production, despite the high prevalence of SCM, which further highlights the problem of SCM passing unnoticed in pastoralist camel herds. Reduction in milk yield is not likely to be detected by herders, because individual quarter milk yield is not measured, and milk yield can vary greatly depending on pasture and water consumption (Bekele et al., 2011). Symptoms indicative of CM, such as induration of udder tissue, were also common findings and could, from the animal owner's perspective, be regarded as "subclinical." A first step toward a control program should be to further investigate the animal owner's own definition of mastitis, to form a knowledge base for future awareness-improving efforts. According to our results, the pastoralists participating in this study lacked knowledge of the appropriate way of handling mastitic camels and their milk. Onefifth of the herders reported that they would abstain from milking camels with $\mathrm{CM}$, in contrast to general recommendations for $\mathrm{CM}$ in bovines of increasing the milking frequency to facilitate and support eradication of pathogens from the udder tissue (Schalm and Mead, 1943; Roberson et al., 2004). Another finding with implications for milk quality, price, and public health was the practice of pooling mastitic milk with milk from apparently healthy camels. Amenu et al. (2017) reported that milk with visual changes indicative of udder health problems would not be discarded by pastoralists but used for tea. Camel milk renders a comparatively high market price, and camel owners and herders generally come from resource-poor settings (Elhadi et al., 2015), which explains the reluctance to let affected milk go to waste. Nevertheless, bacterial counts in infected camel milk can be very high, which can result in severe contamination of the pooled milk. Hence, the lack of hygienic treatment, such as pasteurization, of camel milk along the milk value chain results in a product of poor quality, with severe implications for public health (Kaindi et al., 2011; Wanjohi et al., 2013; Jans et al., 2017).

The difficult hygienic conditions, with limited access to water, under which pastoralist herds operate are likely to play a part in the udder health problems seen in this study, as hand and milking hygiene are cornerstones in interventions for reducing SCM (Goodger et al., 1988; Zucali et al., 2011; Azevedo et al., 2016). Basic milking hygiene practices, such as cleaning of hands and udder before milking, were rarely included in the daily routine among the herds we visited. Basic sanitation of milkers' hands, using a liquid hand disinfectant, 
could be a strategic step toward improving udder health and eliminating contagious udder pathogens (Philpot, 1979). Furthermore, no herds practiced post-milking disinfection of teats. In some of the herds, milking order was practiced, indicating that this routine could be used as a potential intervention for the purpose of reducing SCM (Hutton et al., 1990). Applying disinfectants to the teats after milking significantly reduces the risk of contamination of the teat skin and ascending infections through the teat canal (Oliver et al., 1990). This is another possible SCM-reducing intervention for which implementation in pastoralist settings should be investigated. Considering the limited numbers of herds sampled in this study, our findings with regard to herd management and risk factors are in agreement with other reports from the region (Wayua et al., 2012; Kashongwe et al., 2017). To develop a successful control strategy, the feasibility and efficiency of different interventions should be studied in low-prevalence herds, in comparison with high-prevalence herds.

\section{CONCLUSIONS}

In pastoralist camel herds around Isiolo town, SCM and IMI, specifically caused by Strep. agalactiae, are common udder health problems. The risk of SCM was higher when skin lesions were present on the teats or udder, and risk increased linearly with age and stage of lactation. Increased parity and age were associated with higher risk of IMI and Strep. agalactiae IMI. Risk factors for Strep. agalactiae, such as a previous history of CM, clinical findings of induration of udder tissue, and blind teats all indicate that Strep. agalactiae-derived IMI is likely to develop into a chronic condition. The CMT is a simple and efficient diagnostic tool that could be used for monitoring SCM in camel herds as a control measure to detect IMI-positive camels. Antimicrobial susceptibility testing revealed a large proportion of Strep. agalactiae isolates showing potential resistance to tetracyclines, which have been in use to treat pastoralist livestock in East Africa for longer than any other group of antibiotics. The absence of adequate hygienic practices for milking and handling of mastitic camels are areas that need attention. To reduce the prevalence of SCM, it will be especially important to study the effective implementation of possible interventions under pastoralist herd management and milking conditions.

\section{ACKNOWLEDGMENTS}

The authors extend their gratitude to the Swedish Research Council, which funded this work. We especially thank the pastoralists who participated in the study and Sammy Agui and Mamo Jarso for their tremendous work in the field. Thanks to Ilona Glücks (International Livestock Research Institute, Nairobi, Kenya) for great support, advice, and mentorship. We thank Märit Pringle [Department of Animal Health and Antibiotic Strategies, National Veterinary Institute (SVA), Uppsala, Sweden] for offering guidance on antimicrobial resistance testing and analysis, and Charlotta Fasth at the Mastitis Laboratory, Department of Microbiology, SVA, for invaluable support. The authors have stated that they have no conflicts of interest.

\section{REFERENCES}

Abdulkadhim, M. H. 2012. Prevalence of methicillin resistance Staphylococcus aureus in cattle and she-camels milk at Al-Qadisyia Province. Al-Anbar J. Vet. Sci. 5:63-67.

Abdurahman, O. A. 1996. The detection of subclinical mastitis in the bactrian camel (Camelus bactrianus) by somatic cell count and California mastitis test. Vet. Res. Commun. 20:9-14. https://doi .org/10.1007/BF00346570.

Abdurahman, O. A., H. Agab, B. Abbas, and G. Aström. 1995. Relations between udder infection and somatic cells in camel (Camelus dromedarius) milk. Acta Vet. Scand. 36:423-431.

Abera, M., O. Abdi, F. Abunna, and B. Megersa. 2010. Udder health problems and major bacterial causes of camel mastitis in Jijiga, Eastern Ethiopia: Implication for impacting food security. Trop. Anim. Health Prod. 42:341-347. https://doi.org/10.1007/s11250 -009-9424-6.

Acar, J., and B. Röstel. 2001. Antimicrobial resistance: An overview. Rev. Sci. Tech. 20:797-810. https://doi.org/10.20506/rst.20.3 .1309 .

Adkins, P. R. F., S. Dufour, J. N. Spain, M. J. Calcutt, T. J. Reilly, G. C. Stewart, and J. R. Middleton. 2018. Molecular characterization of non-aureus Staphylococcus spp. from heifer intramammary infections and body sites. J. Dairy Sci. 101:5388-5403. https://doi .org/10.3168/jds.2017-13910.

Agger, J. F., C. Priou, A. Huda, and K. Aagaard. 1994. Risk factors for transmission of Streptococcus agalactiae infection between Danish dairy herds: A case control study. Vet. Res. 25:227-234.

Agger, J. F., and P. Willeberg. 1986. Epidemiology of teat lesions in a dairy herd. II. Associations with subclinical mastitis. Nord. Vet. Med. 38:220-232.

Ahmad, S., M. Yaqoob, M. Q. Bilal, G. Muhammad, L.-G. Yang, M. K. Khan, and M. Tariq. 2012. Risk factors associated with prevalence and major bacterial causes of mastitis in dromedary camels (Camelus dromedarius) under different production systems. Trop. Anim. Health Prod. 44:107-112. https://doi.org/10.1007/s11250 -011-9895-0.

AlAll, A., S. A. Gouda, H. A. Dardir, and A. K. Ibrahim. 2012. Prevalence of some milk borne bacterial pathogens threatening camel milk consumers in Egypt. Glob. Vet. 8:76-82.

Ali, B. H., M. Oukessou, and A. K. Bashir. 1996. Pharmacokinetic considerations in the camel (Camelus dromedarius): A review. Comp. Biochem. Physiol. C Pharmacol. Toxicol. Endocrinol. 115:1-9. https://doi.org/10.1016/S0742-8413(96)00120-X.

Aljumaah, R. S., F. F. Almutairi, M. Ayadi, M. A. Alshaikh, A. M. Aljumaah, and M. F. Hussein. 2011. Factors influencing the prevalence of subclinical mastitis in lactating dromedary camels in Riyadh Region, Saudi Arabia. Trop. Anim. Health Prod. 43:16051610. https://doi.org/10.1007/s11250-011-9877-2.

Amenu, K., B. Szonyi, D. Grace, and B. Wieland. 2017. Important knowledge gaps among pastoralists on causes and treatment of udder health problems in livestock in southern Ethiopia: Results of qualitative investigation. BMC Vet. Res. 13:303. https://doi.org/ 10.1186/s12917-017-1222-1. 
Azevedo, C., D. Pacheco, L. Soares, R. Romão, M. Moitoso, J. Maldonado, R. Guix, and J. Simões. 2016. Prevalence of contagious and environmental mastitis-causing bacteria in bulk tank milk and its relationships with milking practices of dairy cattle herds in São Miguel Island (Azores). Trop. Anim. Health Prod. 48:451-459. https://doi.org/10.1007/s11250-015-0973-6.

Barlow, J. 2011. Mastitis therapy and antimicrobial susceptibility: A multispecies review with a focus on antibiotic treatment of mastitis in dairy cattle. J. Mammary Gland Biol. Neoplasia 16:383-407. https://doi.org/10.1007/s10911-011-9235-z.

Bartlett, P. C., G. Y. Miller, S. E. Lance, D. D. Hancock, and L. E. Heider. 1992. Managerial risk factors of intramammary infection with Streptococcus agalactiae in dairy herds in Ohio. Am. J. Vet. Res. 53:1715-1721.

Bekele, T., N. Lundeheim, and K. Dahlborn. 2011. Milk production and feeding behavior in the camel (Camelus dromedarius) during 4 watering regimens. J. Dairy Sci. 94:1310-1317. https://doi.org/ 10.3168/jds.2010-3654.

Bizzini, A., C. Durussel, J. Bille, G. Greub, and G. Prod'hom. 2010. Performance of matrix-assisted laser desorption ionization-time of flight mass spectrometry for identification of bacterial strains routinely isolated in a clinical microbiology laboratory. J. Clin. Microbiol. 48:1549-1554. https://doi.org/10.1128/JCM.01794-09.

Clinical and Laboratory Standards Institute (CLSI). 2017. Performance Standards for Antimicrobial Susceptibility Testing: M100, S27. 28th ed. CLSI, Wayne, PA.

Cobo-Ángel, C., A. S. Jaramillo-Jaramillo, L. M. Lasso-Rojas, S. B. Aguilar-Marin, J. Sanchez, J. C. Rodriguez-Lecompte, A. Ceballos-Márquez, and R. N. Zadoks. 2018. Streptococcus agalactiae is not always an obligate intramammary pathogen: Molecular epidemiology of GBS from milk, feces and environment in Colombian dairy herds. PLoS One 13:e0208990. https://doi.org/10.1371/ journal.pone.0208990.

Dargent-Molina, P., J. Scarlett, R. V. H. Pollock, H. N. Erb, and P. Sears. 1988. Herd-level risk factors for Staphylococcus aureus and Streptococcus agalactiae intramammary infections. Prev. Vet. Med. 6:127-142. https://doi.org/10.1016/0167-5877(88)90049-9.

Dingwell, R. T., K. E. Leslie, Y. H. Schukken, J. M. Sargeant, L. L. Timms, T. F. Duffield, G. P. Keefe, D. F. Kelton, K. D. Lissemore, and J. Conklin. 2004. Association of cow and quarter-level factors at drying-off with new intramammary infections during the dry period. Prev. Vet. Med. 63:75-89. https://doi.org/10.1016/j prevetmed.2004.01.012.

Dohoo, I. R., S. W. Martin, and H. Stryhn. 2009. Veterinary Epidemiologic Research. VER Incorporated, Charlottestown, Canada.

Elhadi, Y. A., D. M. Nyariki, and O. V. Wasonga. 2015. Role of camel milk in pastoral livelihoods in Kenya: Contribution to household diet and income. Pastoralism 5:8. https://doi.org/10.1186/s13570 -015-0028-7.

Farah, Z., M. Mollet, M. Younan, and R. Dahir. 2007. Camel dairy in Somalia: Limiting factors and development potential. Livest. Sci. 110:187-191. https://doi.org/10.1016/j.livsci.2006.12.010.

Fischer, A., A. Liljander, H. Kaspar, C. Muriuki, H.-H. Fuxelius, E. Bongcam-Rudloff, E. P. de Villiers, C. A. Huber, J. Frey, C. Daubenberger, R. Bishop, M. Younan, and J. Jores. 2013. Camel Streptococcus agalactiae populations are associated with specific disease complexes and acquired the tetracycline resistance gene tetM via a Tn916-like element. Vet. Res. 44:86. https://doi.org/10 .1186/1297-9716-44-86.

Goodger, W. J., J. C. Galland, and V. E. Christiansen. 1988. Survey of milking management practices on large dairies and their relationship to udder health and production variables. J. Dairy Sci. 71:2535-2542. https://doi.org/10.3168/jds.S0022-0302(88)79842 $-2$.

Guliye, A. Y., I. M. Noor, B. O. Bebe, and I. S. Kosgey. 2007. Role of camels (Camelus dromedarius) in the traditional lifestyle of Somali pastoralists in northern Kenya. Outlook Agric. 36:29-34. https:// doi.org/10.5367/000000007780223669.

Husein, A., B. Haftu, A. Hunde, and A. Tesfaye. 2013. Prevalence of camel (Camelus dromedarius) mastitis in Jijiga Town, Ethiopia. Afr. J. Agric. Res. 8:3113-3120. 10.5897/AJAR2013.6913.
Hutton, C. T., L. K. Fox, and D. D. Hancock. 1990. Mastitis control practices: Differences between herds with high and low milk somatic cell counts. J. Dairy Sci. 73:1135-1143. https://doi.org/10 .3168/jds.S0022-0302(90)78774-7.

Jans, C., A. Merz, S. Johler, M. Younan, S. A. Tanner, D. W. M. Kaindi, J. Wangoh, B. Bonfoh, L. Meile, and T. Tasara. 2017. East and West African milk products are reservoirs for human and livestock-associated Staphylococcus aureus. Food Microbiol. 65:64-73. https://doi.org/10.1016/j.fm.2017.01.017.

Jørgensen, H. J., A. B. Nordstoga, S. Sviland, R. N. Zadoks, L. Sølverød, B. Kvitle, and T. Mørk. 2016. Streptococcus agalactiae in the environment of bovine dairy herds - Rewriting the textbooks? Vet. Microbiol. 184:64-72. https://doi.org/10.1016/j.vetmic.2015 .12.014.

Kaindi, D. W. M., E. Schelling, J. M. Wangoh, J. K. Imungi, Z. Farah, and L. Meile. 2011. Risk factors for gastrointestinal illness in rural town Isiolo, Kenya. Zoonoses Public Health 59:118-125. https:// doi.org/10.1111/j.1863-2378.2011.01425.x.

Kashongwe, O. B., B. O. Bebe, J. W. Matofari, and C. G. Huelsebusch. 2017. Associations between milking practices, somatic cell counts and milk postharvest losses in smallholder dairy and pastoral camel herds in Kenya. Int. J. Vet. Sci. Med. 5:57-64. https:// doi.org/10.1016/j.ijvsm.2017.01.001.

Kemp, M. H., A. M. Nolan, P. J. Cripps, and J. L. Fitzpatrick. 2008. Animal-based measurements of the severity of mastitis in dairy cows. Vet. Rec. 163:175-179. https://doi.org/10.1136/vr.163.6 .175 .

Kenya National Bureau of Statistics. 2010. Population and housing census 2009. Ministry of Finance and Planning, Nairobi, Kenya.

Klastrup, O., and P. S. Madsen. 1974. Nordiske rekommendationer vedrorende mastitisundersogelser af kirtelprover (Nordic recommendations concerning mastitis control of quarter samples). Nordic Veterinarmed. 26:197-204.

Köhler-Rollefson, I., B. E. Musa, and M. F. Achmed. 1991. The camel pastoral system of the southern Rashaida in eastern Sudan. Nomad. People. 29:68-76.

Kotb, S., M. Sayed, and A. Abdel-Rady. 2010. Sanitary conditions of lactating dromedary she-camel environment with special reference to milk quality and subclinical mastitis monitoring. Emir. J. Food Agric. 22:207-215. https://doi.org/10.9755/ejfa.v22i3.4890.

Lamuka, P. O., F. M. Njeruh, G. C. Gitao, and K. A. Abey. 2017. Camel health management and pastoralists' knowledge and information on zoonoses and food safety risks in Isiolo County, Kenya. Pastoralism 7:20. https://doi.org/10.1186/s13570-017-0095-z.

Levy, S. B., and B. Marshall. 2004. Antibacterial resistance worldwide: Causes, challenges and responses. Nat. Med. 10(Suppl. 12):S122S129. https://doi.org/10.1038/nm1145.

Mati, B., J. M. Muchiri, K. Njenga, F. P. de Vries, and D. J. Merrey. 2005. Assessing water availability under pastoral livestock systems in drought-prone Isiolo District, Kenya (Working Paper). International Water Management Institute (IWMI), Colombo, Sri Lanka.

Matofari, J.W., A. Shitandi, P. L. Shalo, and J. N. Nanua., and M. Younan. 2007. A survey of Salmonella enterica contamination of camel milk in Kenya. Afr. J. Microbiol. Res. 1:46-50.

Matofari, J. W., M. Younan, J. N. Nanua, E. W. Mwatha, and P. O. Okemo. 2005. Microorganisms associated with sub-clinical mastitis and their impact on milk production in camels (Camelus dromedarius) in semi-arid lands of Northern Kenya. Int. J. Agric. Rural Dev. 6:182-187. https://doi.org/10.4314/ijard.v6i1.2607.

Miller, R. H., U. Emanuelsson, E. Persson, L. Brolund, J. Philipsson, and H. Funke. 1983. Relationships of milk somatic cell counts to daily milk yield and composition. Acta Agric. Scand. 33:209-223. https://doi.org/10.1080/00015128309439885.

Munene, E. 2018. Statistical Abstract 2017. Kenya Natl. Bur. Stat. Accessed Aug. 23, 2019. https://www.knbs.or.ke/statistical-abstract $-2017 /$.

Musinga, M., D. Kimenye, P. Kivolonzi, and Resource Mobilisation Centre. 2008. The Camel Milk Industry in Kenya. Netherlands Development Organisation (SNV), the Hague, the Netherlands.

Mutua, J. M., C. G. Gitao, L. C. Bebora, and F. K. Mutua. 2017. Antimicrobial resistance profiles of bacteria isolated from the 
nasal cavity of camels in Samburu, Nakuru, and Isiolo Counties of Kenya. J. Vet. Med. 2017:1-6. https://doi.org/10.1155/2017/ 1216283.

Nagy, P., B. Faye, O. Marko, S. Thomas, U. Wernery, and J. Juhasz. 2013. Microbiological quality and somatic cell count in bulk milk of dromedary camels (Camelus dromedarius): Descriptive statistics, correlations, and factors of variation. J. Dairy Sci. 96:56255640. https://doi.org/10.3168/jds.2013-6990.

Nagy, P., and J. Juhasz. 2016. Review of present knowledge on machine milking and intensive milk production in dromedary camels and future challenges. Trop. Anim. Health Prod. 48:915-926. https://doi.org/10.1007/s11250-016-1036-3.

Nielsen, C., S. Østergaard, U. Emanuelson, H. Andersson, B. Berglund, and E. Strandberg., 2010. Economic consequences of mastitis and withdrawal of milk with high somatic cell count in Swedish dairy herds. Animal 4:1758-1770. https://doi.org/10.1017/ S1751731110000704.

Noor, I. M., A. Y. Guliye, M. Tariq, and B. O. Bebe. 2013. Assessment of camel and camel milk marketing practices in an emerging periurban production system in Isiolo County, Kenya. Pastor. Res. Policy Pract. 3:28. https://doi.org/10.1186/2041-7136-3-28.

Obied, A. I., H. O. Bagadi, and M. M. Mukhtar. 1996. Mastitis in Camelus dromedarius and the somatic cell content of camels' milk. Res. Vet. Sci. 61:55-58. https://doi.org/10.1016/S0034 $-5288(96) 90111-3$.

Oliver, S. P., S. H. King, M. J. Lewis, P. M. Torre, K. R. Matthews, and H. H. Dowlen. 1990. Efficacy of chlorhexidine as a postmilking teat disinfectant for the prevention of bovine mastitis during lactation. J. Dairy Sci. 73:2230-2235. https://doi.org/10.3168/jds .S0022-0302(90)78903-5.

Philpot, W. N. 1979. Control of mastitis by hygiene and therapy. J. Dairy Sci. 62:168-176. https://doi.org/10.3168/jds.S0022 -0302(79)83218-X.

Ramadan, R. O., A. M. el Hassan, R. Abdin-Bey, Y. A. Algasnawi, E. S. Abdalla, and A. A. Fayed. 1987. Chronic obstructive mastitis in the camel: A clinicopathological study. Cornell Vet. 77:132-150.

Regassa, A., G. Golicha, D. Tesfaye, F. Abunna, and B. Megersa. 2013. Prevalence, risk factors, and major bacterial causes of camel mastitis in Borana Zone, Oromia Regional State, Ethiopia. Trop. Anim. Health Prod. 45:1589-1595. https://doi.org/10.1007/s11250 -013-0403-6.

Roberson, J. R., L. D. Warnick, and G. Moore. 2004. Mild to moderate clinical mastitis: Efficacy of intramammary amoxicillin, frequent milk-out, a combined intramammary amoxicillin, and frequent milk-out treatment versus no treatment. J. Dairy Sci. 87:583-592. https://doi.org/10.3168/jds.S0022-0302(04)73200-2.

Saleh, S. K., G. Al-Ramadhan, and B. Faye. 2013. Monitoring of monthly SCC in she-camel in relation to milking practice, udder status and microbiological contamination of milk. Emir. J. Food Agric. 25:403-408. https://doi.org/10.9755/ejfa.v25i5.15512.

Sandholm, M., ed. 1995. The Bovine Udder and Mastitis. University of Helsinki, Faculty of Veterinary Medicine, Helsinki, Finland.

Schalm, O. W., and S. W. Mead. 1943. The effect of incomplete milking on chronic mastitis caused by Streptococcus agalactiae. J. Dairy Sci. 26:823-832. https://doi.org/10.3168/jds.S0022-0302(43)92775 -4 .
Schalm, O. W., and D. O. Noorlander. 1957. Experiments and observations leading to development of the California Mastitis Test. J. Am. Vet. Med. Assoc. 130:199-204.

Schukken, Y. H., J. H. Smit, F. J. Grommers, D. Vandegeer, and A. Brand. 1989. Effect of freezing on bacteriologic culturing of mastitis milk samples. J. Dairy Sci. 72:1900-1906. https://doi.org/10 .3168/jds.S0022-0302(89)79309-7.

Taponen, S., L. Salmikivi, H. Simojoki, M. T. Koskinen, and S. Pyörälä. 2009. Real-time polymerase chain reaction-based identification of bacteria in milk samples from bovine clinical mastitis with no growth in conventional culturing. J. Dairy Sci. 92:26102617. https://doi.org/10.3168/jds.2008-1729.

Toroitich, K.C., G.K. Gitau, P.M. Kitala, and G.C. Gitao., 2017. The prevalence and causes of mastitis in lactating traditionally managed one-humped camels (Camelus dromedarius) in West Pokot County, Kenya. Livest. Resarch Rural Dev. 29:64. http://www.lrrd .org/lrrd29/4/gita29062.html.

Volpato, G., and P. Howard. 2014. The material and cultural recovery of camels and camel husbandry among Sahrawi refugees of Western Sahara. Pastoralism 4:7. https://doi.org/10.1186/s13570-014 $-0007-4$.

Volpato, G., S. M. Lamin Saleh, and A. Di Nardo. 2015. Ethnoveterinary of Sahrawi pastoralists of Western Sahara: Camel diseases and remedies. J. Ethnobiol. Ethnomed. 11:54. https://doi.org/10 $.1186 / \mathrm{s} 13002-015-0040-4$.

Wang, H., T. Wang, B. Zhang, F. Li, B. Toure, I.B. Omosa, T. Chiramba, M. Abdel-Monem, and M. Pradhan., 2014. Water and wastewater treatment in Africa-Current practices and challenges. CLEAN—Soil Air Water 42:1029-1035. https://doi.org/10.1002/ clen.201300208.

Wanjohi, M., C. G. Gitao, and L. Bebora. 2013. Subclinical mastitis affecting hygienic quality of marketed camel milk from NorthEastern Province, Kenya. Microbiol. Res. Int. 1:6-15.

Wayua, F. O., M. W. Okoth, and J. Wangoh. 2012. Survey of postharvest handling, preservation and processing practices along the camel milk chain in Isiolo district, Kenya. Afr. J. Food Agric Nutr. Dev. 12:6897-6912.

Wyder, A. B., R. Boss, J. Naskova, T. Kaufmann, A. Steiner, and H. U. Graber. 2011. Streptococcus spp. and related bacteria: Their identification and their pathogenic potential for chronic mastitisA molecular approach. Res. Vet. Sci. 91:349-357. https://doi.org/ 10.1016/j.rvsc.2010.09.006.

Younan, M., Z. Ali, S. Bornstein, and W. Müller. 2001. Application of the California Mastitis Test in intramammary Streptococcus agalactiae and Staphylococcus aureus infections of camels (Camelus dromedarius) in Kenya. Prev. Vet. Med. 51:307-316. https://doi .org/10.1016/S0167-5877(01)00228-8.

Younan, M., and S. Bornstein. 2007. Lancefield group B and C streptococci in East African camels (Camelus dromedarius). Vet. Rec. 160:330-335. https://doi.org/10.1136/vr.160.10.330.

Zucali, M., L. Bava, A. Tamburini, M. Brasca, L. Vanoni, and A. Sandrucci. 2011. Effects of season, milking routine and cow cleanliness on bacterial and somatic cell counts of bulk tank milk. J. Dairy Res. 78:436-441. https://doi.org/10.1017/S0022029911000598. 